\title{
The Examination of the Appearance of CSR in On-line Scientific Databases
}

\author{
Lívia Benita Kiss
}

$\mathrm{PhD}$ student, Pannon University, PhD School of Management Sciences and Business Administration, Hungary

\begin{abstract}
The phrase, corporate social responsibility (or CSR) has become very popular in recent years. A lot of definitions are in the literature. There is no generally agreed definition of corporate social responsibility (or CSR). According to the literature I think so the corporate social responsibility is a corporation's initiatives to assess and take responsibility for the company's effects on environmental and social wellbeing. Based on the literature, I think that the definition of corporate social responsibility (or CSR) can be classified into two general schools of thought. Corporate social responsibility (or CSR) is central to a whole range of concepts and issues relating to businesses and their role in society. It is useful to briefly consider where the idea of corporate social responsibility came from, when and how it has developed. In understanding corporate social responsibility, it is important to examine the genesis of the phrase, its meaning and its application and occurrence in scientific life. The goal of my study is to investigate when and where the corporate social responsibility (or CSR) appears in on-line scientific databases. I searched in databases when the phrase used first. I examined the frequency of appearance of corporate social responsibility (or CSR) in databases. The frequency of appearance of corporate social responsibility (or CSR) was 556,220 in on-line databases. The phrase was mostly in journals and in articles. The frequency of appearance of corporate social responsibility shows an exponential increasing trend in databases. The corporate social responsibility is occurring in more and more scientific research and publications. The first appearance of the investigated phrase in databases was in 1792 in all sciences. The first appearance of the investigated phrase in databases was in 1886 in selected (economic and business) sciences.
\end{abstract}

Keywords: CSR, databases, content analysis.

JEL Classifications: M14, C22, C89.

(C) The Author, 2018. This article is published with open access at Sumy State University.

\section{Introduction}

The phrase, corporate social responsibility (CSR) has become very popular in recent years. Businesses and academics researchers have been showing great interests in corporate social responsibility during the recent years (Maignan et al., 2002). CSR is central to a whole range of concepts and issues relating to businesses and their role in society. It is useful to briefly consider where the idea of corporate social responsibility came from, when and how it has developed. In understanding corporate social responsibility, it is important to examine the genesis of the phrase, its meaning and its application and occurrence in scientific life.

Some texts already in ancient times included material suggestion that moral obligations existed for those engaging in trade and commerce. The first substantial publications on the role of business in society can be traced to as early as 1930 's. Only in the 1960's the corporate social responsibility emerged as an area of general concern for companies. This reflected increasing pressures on placed on companies to assume a greater responsibility for correcting the harmful impacts of their operations, a role traditionally performed by society as a whole. The corporate social responsibility was seen as method self-regulation distinct from both government legislation and managerial ethics in this context. By the 1980's governments had introduced legislation on many of the issues that had lead to the emergence of corporate social responsibility in the 1960's (Hinson, 2015).

The newest and the most modern wave of interest in corporate social responsibility have been marked by some new development. The dispute is now more about how to make substantial commitments rather than whether to make them at all. There has been an increasing interest in the topic in Europe initiatives on corporate social responsibility (Hinson, 2015). 


\section{Definitions of CSR}

There is no generally agreed definition of CSR. The history of corporate social responsibility is almost as old as that of companies. The idea of corporate social responsibility has developed differently around the world because of unique histories, cultures and institutions in the words of Steiner (1971). Based on the literature, I think that the definition of CSR can be classified into two general schools of thought.

Firstly, there are those such as Friedman (1970) and Levitt (1958), who claim that the obligation of an organization is to maximize profits by abiding by the corporate rules that prevails, with minimum ethical constraints. Within the first group, two further groups can be distinguished. Some writers have taken the view, among them Friedman that a corporation should not be concerned with social responsibility. Other people such as Drucker (1984) are more cynical in their view of corporate activity.

Secondly, those such as Davis et al. (1975), Epstein (1987) and McGuire (1963), who place greater emphasis on the organization's obligations towards the society. From the perspective of the second main group, in the following I present the development of CSR's definition in chronological order.

Carnegie published a book called The Gospel of Wealth In 1899. Carnegie's view was based on two principles: the charity principle and the stewardship principle, which set forth the classic statement of corporate social responsibility.

40 years later Barnard (1938) defined CSR as analyses economic, social, physical, legal and moral aspects of environment.

CSR is an obligation according to Bowen (1953) that arises from the impact corporate decisions and actions have on the lives of people.

Dahl (1972: 18) defined "every large corporation should be thought of as a social enterprise; that is an entity whose existence and decisions can be justified insofar as they serve public or social purposes".

Davis (1973: 313) stated CSR as "the firm's consideration of, and response to, issues beyond the narrow economic, technical, and legal requirements of the firm".

However, the desirability of considering the social performance of a business has not always been accepted. According to Hetherington (1973: 37), "there is no reason to think that shareholders are willing to tolerate an amount of corporate non-profit activity which appreciably reduces either dividends or the market performance of the stock".

The early CSR theorists, Carroll (1979: 501) stated that "business encompasses the economic, legal, ethical and discretionary expectations that society has of organization at a given point in time". From 1991 the basis of what I consider to be the modern definition of CSR is rooted in Carroll's pyramid of corporate social responsibility. A corporation has four types of responsibilities in this pyramid: economic, legal, ethical and philanthropic (Figure 1).

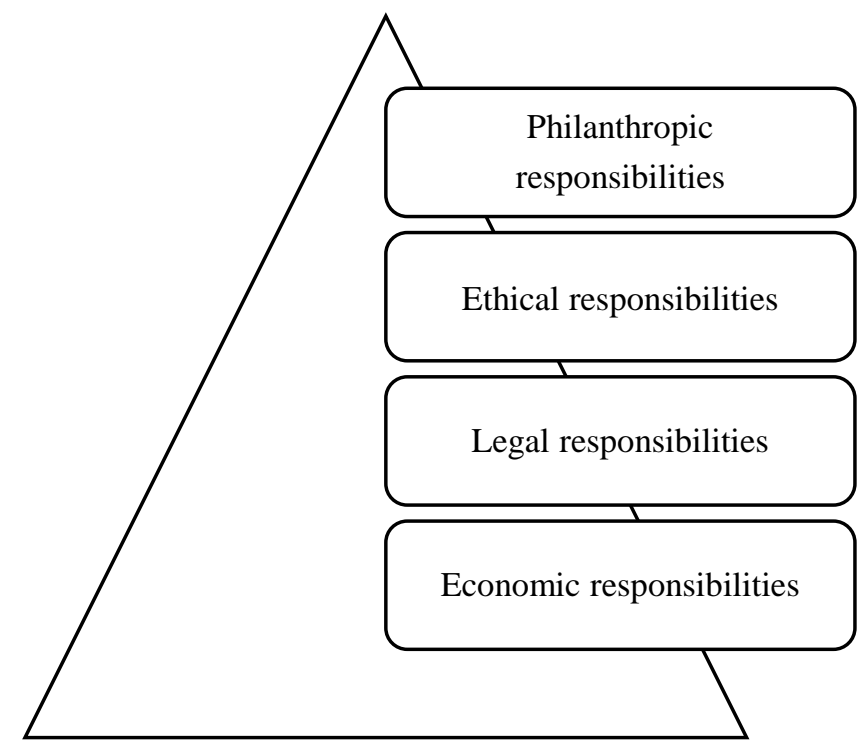

Source: own editing

Figure 1. Carroll's CSR Pyramid 
The most important responsibility is the economic. The company must be profitable. The legal responsibility means compliance with the law. The ethical responsibility means what is right in the business life. The philanthropic responsibility is the discretionary responsibility. The company is support for social, educational and cultural purposes (Carroll, 1991).

20 years ago, Balabanis et al. (1998) declared that companies and their managers are pressure to play an increasingly active role in the welfare of society in the modern commercial area.

McWilliams et al. (2001: 117) defined CSR as "actions that appear to further some social good beyond the interest of the firm and which are required by law".

According to Forstater et al. (2002) CSR is a company's actions that contribute through the company's core business activities, social investment and public policy debate to sustainable development.

The concept of the corporate social responsibility became cardinal importance in business life and in periodically reporting. Today most companies have a CSR policy, which determines their business. Corporations' leaders claim that they are able to recognize corporate activity which is socially responsible and which is not socially responsible (Crowther et al., 2008).

\section{CSR by organizations}

EU Commission $(2001,2002)$ defines CSR as a concept. Companies weave social and environmental commitments into their generally business activity. According to Commission, that CSR is determinant and relevant for the economic growth, sustainable development, competitiveness, effectiveness and innovation. CSR brings a lot of benefits for economy of EU.

This definition was changed in 2011 by the EU. CSR means in new understanding it that every company has an impact on the responsibility. CSR is not just a voluntary company action in the definition. The areas of CSR have been expanded with human rights, consumer concern and ethical. The areas of CSR were earlier just environment and society (Martinuzzi et al., 2011). The new EU Commission's strategy is that help companies create jobs, prosperity. The new strategy describes how the company can profit from CSR. This new definition takes into account all internationally recognized CSR principles and guidelines (EU Commission, 2011).

According to The World Business Council for Sustainable Development, the CSR rests on the fundamental pillars of both the economic growth and the quality of life as an engine for sustainable development (Holme et al., 2000).

According to World Bank (2006), CSR is a contribution to the sustainable economic development. Aims of CSR are that contribute to improving the quality of life and welfare, while also serving business goals.

Socially responsible initiatives by entrepreneurs have a long tradition in throughout Europe. CSR depends on the particular situation of individual companies in which they operate, be it in Europe or elsewhere (Militaru et al., 2006).

Despite the wide spectrum of approaches to CSR, there is large consensus on its three main features (Horrigan, 2010) which are the followers: CSR is

behavior by businesses over and above legal requirements, voluntarily adopted because businesses deem it to be in their long-term interest;

intrinsically linked to the concept of sustainable development: businesses need to integrate the economic, social and environmental impact in their operations;

$>$ not an optional "add-on" to business core activities - but about the way in which businesses are managed.

\section{Principles and key drivers of CSR}

Because of the uncertainty surrounding the nature of CSR activity, it is difficult to define CSR. There are three basic principles (Figure 2) which together comprise all CSR activity. These are sustainability, accountability and transparency (Crowther et al., 2008). 


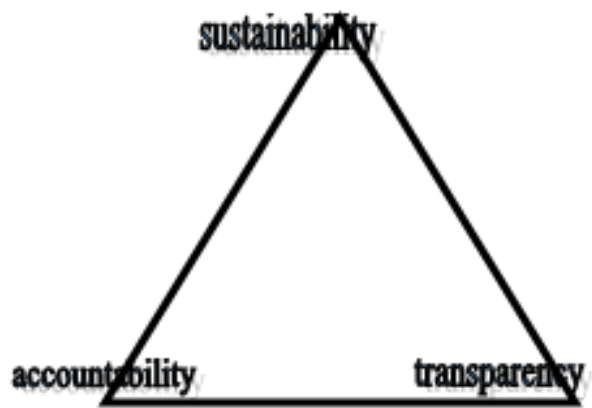

Figure 2. CSR principles

Source: own editing

Accountability an organization must recognize that its actions generally affect the external environment and therefore assume responsibility for the effects of its actions. Sustainability implies that society must at all times use no more of its resources than can be generated. The actions of the present have recurring effects upon the opportunities of the future. Transparency indicates that corporations make report of their actions. That report gives detailed, accurate and understandable information. (Hinson, 2015).

Key drivers of CSR engagements in recent years have been identified as:

crises management,

communications,

$>$ corporate sector impact,

$>$ finance,

$>$ globalization,

$>$ governance,

$>$ ethical consumerism,

$>$ social awareness and education,

$>$ strategic business tool,

$>$ sustainable development.

Nowadays, more and more companies think that the company can still be successful in the long run, if the company is market-oriented, but it operates responsibly. The companies realized that they can contribute to sustainable economy and development. The company takes into account the environmental protection and the CSR in its operations, while remaining competitive. The number of companies is growing steadily, which take into account the CSR (Crowther et al., 2008).

Based on the above CSR is a changeable and contested theme and area. Not everyone thinks it that CSR have a relevant role in modern business (Crowther et al., 2008).

\section{Material and Methods}

The goal of study is to investigate when and where the corporate social responsibility (or CSR) appears in online scientific databases. I will search in databases when the phrase first used. The search was made between 10 February and 28 February. Data preparation and result evaluation was carried out in Microsoft Office Excel.

The most significant online international databases - such as Science Direct - were chosen for the frequency analysis of the phrase, so a quantitative content analysis was carried out.

According to Gyuris, it can be noted that the national works relating to the topic (especially researches of local inequalities) are mostly built upon the approach of the 1950`s and 1960`s American social scientific thinking`s conceptional and methodical foundations (Gyuris, 2014). Content analysis is a relatively new method in the field of social science. The first methodical book (Content analysis in communication research), that deals with content analysis, was published in 1952 and written by Berelson, and founded quantitative content analysis, which is considered to be the classic form of the method.

Table 1. summarizes the most important characteristics of six databases which are relevant for the study. 
Table 1. The most important characteristics of databases

\begin{tabular}{|c|c|c|c|}
\hline $\begin{array}{c}\text { Database } \\
\text { title }\end{array}$ & All year & $\begin{array}{c}\text { Publication } \\
\text { type }\end{array}$ & $\begin{array}{l}\text { Database } \\
\text { size }\end{array}$ \\
\hline Science Direct & $1823-2018$ & journal, book, reference work & $\begin{array}{l}\text { over } 3,800 \text { journals and more } \\
\text { than } 37,000 \text { book }\end{array}$ \\
\hline JSTOR & $1792-2018$ & $\begin{array}{c}\text { article, review, book, research report, pamphlet, } \\
\text { miscellaneous }\end{array}$ & $\begin{array}{l}\text { more than } 10 \text { million academic } \\
\text { journal articles, books }\end{array}$ \\
\hline Springer Link & $1815-2018$ & $\begin{array}{l}\text { article, chapter, book, book series, protocol, } \\
\text { reference work, conference paper, conference } \\
\text { proceeding, journal, reference work entry }\end{array}$ & $\begin{array}{l}\text { over } 10 \text { million scientific } \\
\text { documents }\end{array}$ \\
\hline $\begin{array}{c}\text { Taylor } \\
\text { \& Francis Online } \\
\end{array}$ & $1798-2018$ & article, journal, database & $\begin{array}{c}\text { over } 13 \text { million pages from } 1,200 \\
\text { journals }\end{array}$ \\
\hline $\begin{array}{c}\text { Wiley } \\
\text { Online Library }\end{array}$ & $\mathrm{xxxx}-2018$ & $\begin{array}{l}\text { journal, book, reference work, } \\
\text { database, lab protocol }\end{array}$ & $\begin{array}{l}6 \text { million articles from over } \\
1,500 \text { journals, over } 20,000 \\
\text { online books, and hundreds of } \\
\text { reference works, laboratory } \\
\text { protocols and databases. }\end{array}$ \\
\hline $\begin{array}{c}\text { Google } \\
\text { Books }\end{array}$ & $1800-2018$ & book & over 5 million books \\
\hline
\end{tabular}

Source: own editing

The examined databases are very large. Each database contains millions of documents from the 1700's or the 1800 's to present.

The Google Books Ngram Viewer is an online search platform for Google' text. Man can search between 1900 and 2008 in Google's text in different languages. When you enter phrases into the Google Books Ngram Viewer, it displays a graph showing how those phrases have occurred in a corpus of books over the selected years (https://books.google.com/ngrams/info).

\section{Results and Discussions}

In the following, I summarize the first appearance of the investigated phrase in databases. After that time I have done the frequency analysis of the phrase corporate social responsibility (or CSR) in each database.

\section{First appearance of CSR in databases}

Table 2. summarizes the first appearance of the investigated phrase in databases. In some cases the text had to be examined deeper, including the wording and the use of the phrase itself, to ensure that its use was relevant to the investigated topic. I searched for the phrase in all documents and in selected sciences of databases.

Table 2. First appearance of corporate social responsibility (or CSR) in databases in all sciences and in selected sciences

\begin{tabular}{|c|c|c|c|}
\hline Database & Publication & In all sciences & $\begin{array}{c}\text { Year of first } \\
\text { appearance }\end{array}$ \\
\hline Science Direct & The Lancet & $\begin{array}{c}\text { St. Thomas's and Guy's Hospitals, Anniversary } \\
\text { Dinner } \\
\text { (article) }\end{array}$ & 1824 \\
\hline JSTOR & Cowen Tracts & $\begin{array}{c}\text { A reply to Mr. Burke's invective against Mr. } \\
\text { Cooper and Mr. Watt in the House of Commons } \\
\text { (pamphlet) }\end{array}$ & 1792 \\
\hline Springer Link & $\begin{array}{c}\text { Dublin Quarterly Journal } \\
\text { of Medical Science }\end{array}$ & $\begin{array}{c}\text { Reviews and bibliographical notices } \\
\text { (article) }\end{array}$ & 1851 \\
\hline Database & \multicolumn{2}{|c|}{ In selected sciences - economic and business sciences } & $\begin{array}{c}\text { Year of first } \\
\text { appearance }\end{array}$ \\
\hline Science Direct & Publication & $\begin{array}{c}\text { Journal/Book title } \\
1957\end{array}$ \\
\hline JSTOR & $\begin{array}{r}\text { American Economic } \\
\text { Association }\end{array}$ & Book notes & 1886 \\
\hline Springer Link & $\begin{array}{r}\text { Dictionary of Political } \\
\text { Economy }\end{array}$ & $\begin{array}{c}\text { Cooperation in a Western City } \\
\text { (article) }\end{array}$ & 1899 \\
\hline
\end{tabular}

Source: own editing 
I mentioned earlier that various texts in ancient times included material suggestion that moral obligations existed for those engaging in trade and commerce. The first substantial publications on the role of business in society can be traced to as early as 1930 's.

In three databases - Science Direct, JSTOR and Springer Link - I had an opportunity for this search mode. The result is two journal articles and one pamphlet. The pamphlet was published in 1792 in Cowen Tracts. This publication is in JSTOR databases. This document is the earliest. Two articles appeared in other two databases - Science Direct and Springer Link - in health journals.

The selected sciences were economic and social sciences. The table contains received results in economic and business sciences. The result is a journal articles, a chapter and a book note. The pamphlet was published in 1886 in American Economic Association. This publication is in JSTOR databases.

\section{Frequency of appearance analysis of CSR}

In the following, select examples of the frequency analysis of the phrase corporate social responsibility (or CSR) are going to be detailed.

Figure 3. shows frequency of appearance of corporate social responsibility (or CSR) in on-line databases in all sciences. The corporate social responsibility (or CSR) included 556220 times in the examined databases. The phrase was mostly in the database of JSTOR. The phrase was the least in Science Direct's database. Naturally, the size of each database was influenced the result. JSTOR resulted in slightly over 150000 hits for the searched attributes. Science Direct resulted in slightly over 80000 hits for the searched attributes.

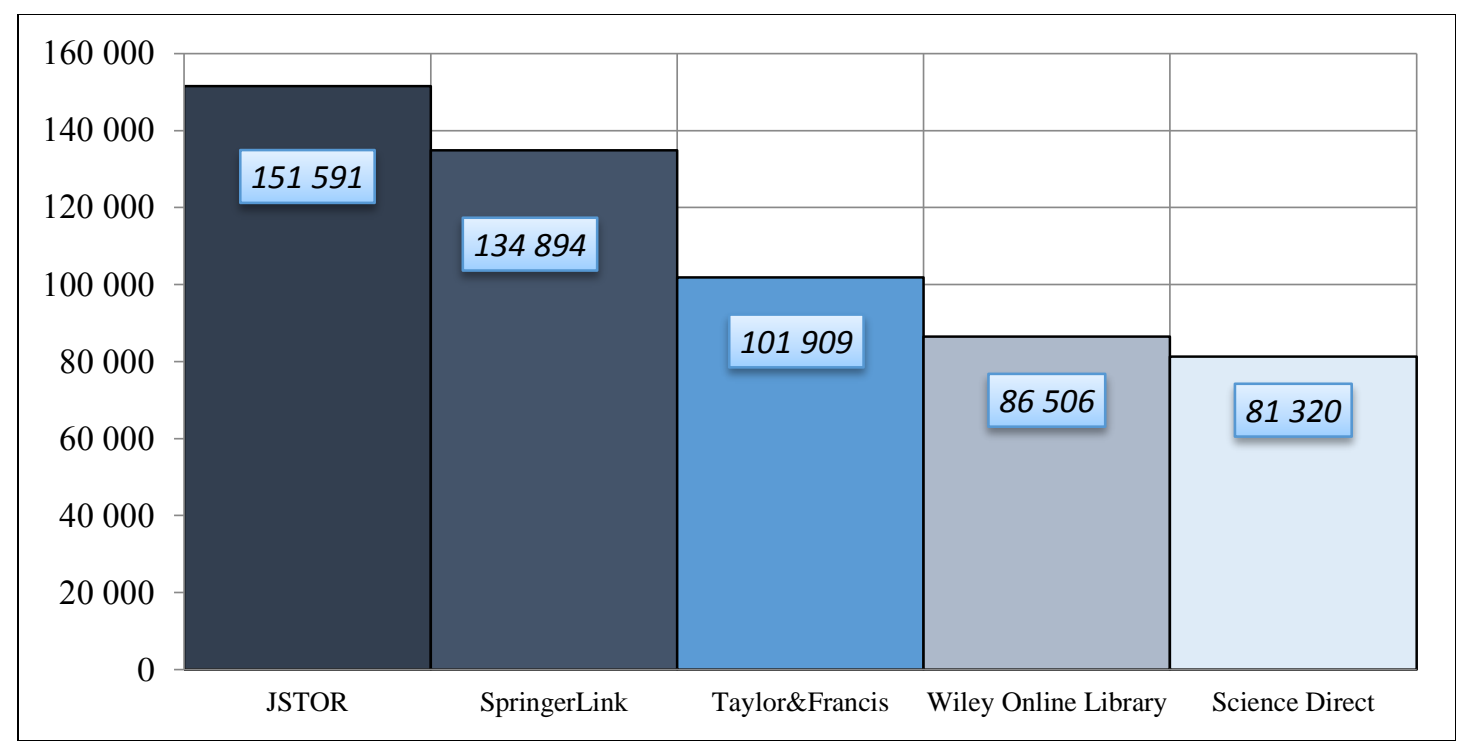

Figure 3. Frequency of appearance of corporate social responsibility (or CSR) in on-line databases

Source: own compilation based on databases

Figure 4. shows frequency of appearance of corporate social responsibility (or CSR) in on-line databases publication by type. The phrase was mostly in journals and in articles. The frequency of appearance of corporate social responsibility in pamphlet was 615 , in database was 454, in research report was 365 and in protocol/lab protocol was 60 . 


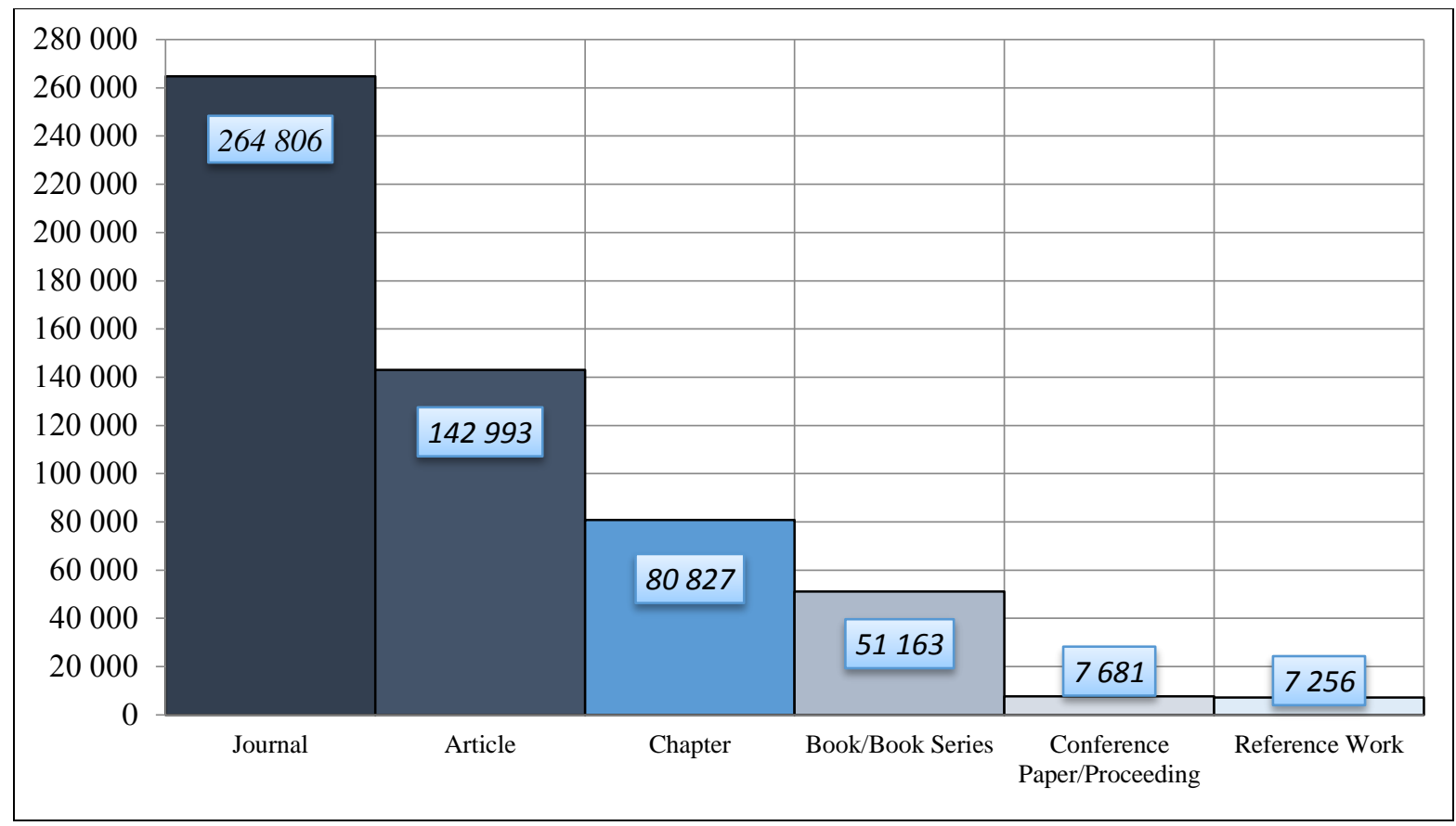

Figure 4. Frequency of appearance of corporate social responsibility (or CSR) in on-line databases publication by type Source: own compilation based on databases

Figure 5. shows the frequency of appearance of corporate social responsibility (or CSR) in the Google Books' database in chronological order between 1900 and 2008. Using the corporate social responsibility (or CSR) phrase show an exponential trend. The value of $\mathrm{R}^{2}(0.8865)$ shows a good fit.

From 1900 to 1980 the frequency of appearance of corporate social responsibility in the Google Books database has been growing continuously. In the 1980's it has been decreasing gradually, then stagnated. From the second half of the 1990's I can see another growth. In the 2000's and in present this growth was very significant.

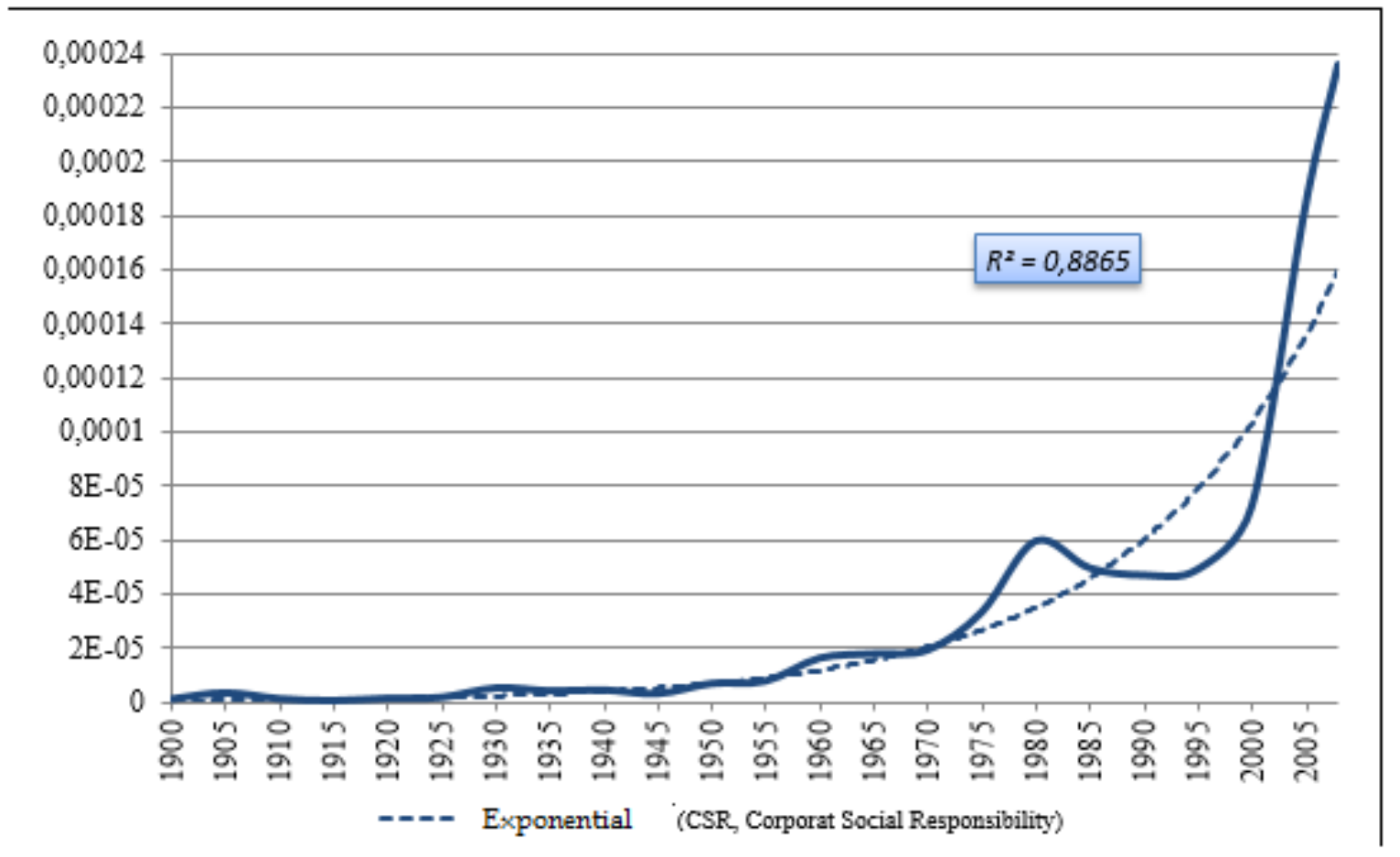

Figure 5. Frequency of appearance of corporate social responsibility (or CSR) in the Google Books`database Source: own editing 
Figure 6. shows the frequency of appearance of corporate social responsibility (or CSR) in the Science Direct database in all sciences and in selected sciences in chronological order between 1900 and 2017. Using the corporate social responsibility (or CSR) phrase show an exponential trend in all sciences. The value of $\mathrm{R}^{2}$ (0.9138) shows a good fit. From 1900 to 1970 the frequency of appearance of corporate social responsibility in the Science Direct's database was not significant. In the 2000's and in present this growth was very significant.

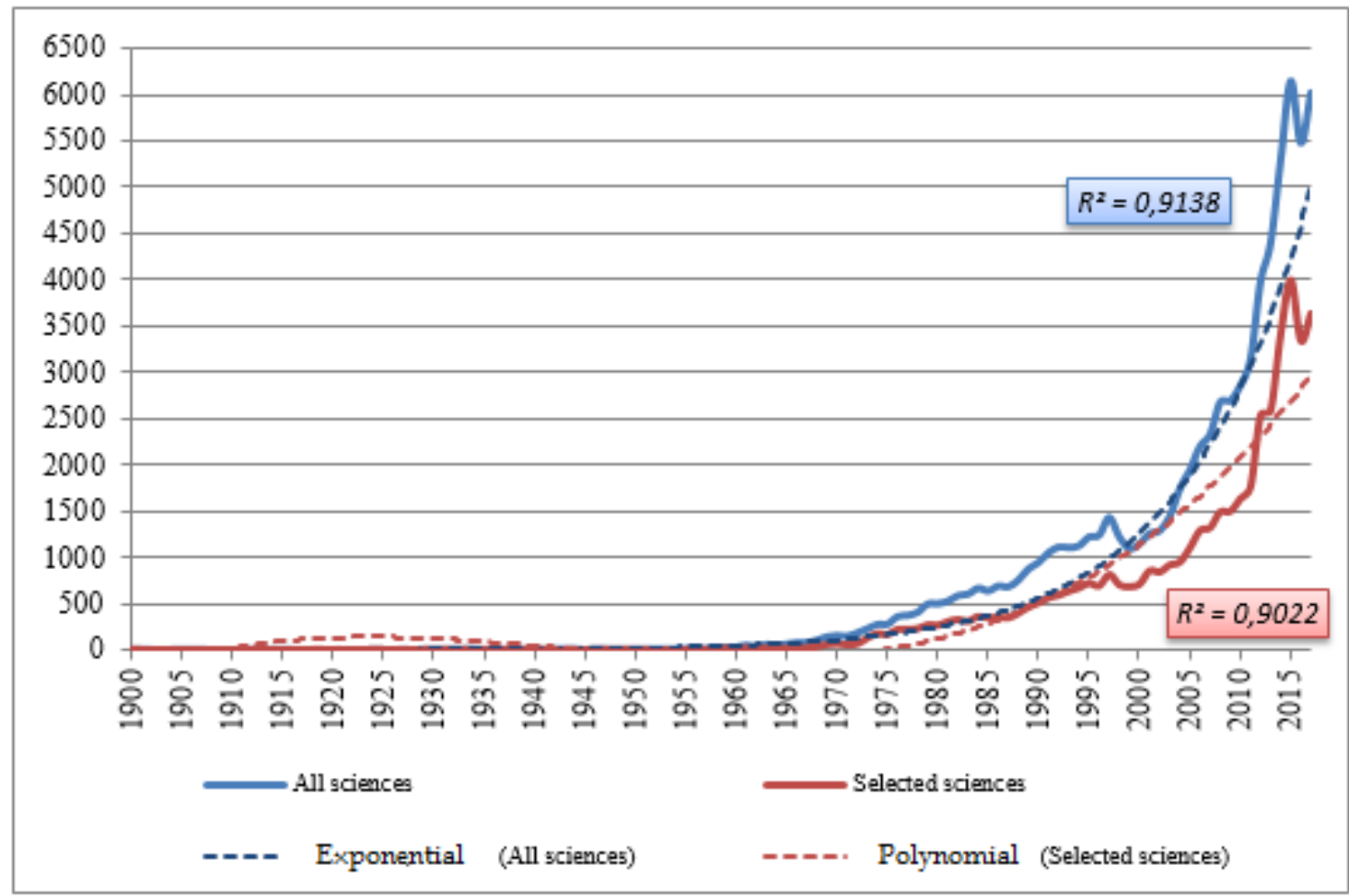

Figure 6. Frequency of appearance of corporate social responsibility (or CSR) in the Science Direct's database in all sciences Source: own editing and in selected sciences

Using the corporate social responsibility (or CSR) phrase show a polynomial trend in selected sciences. The value of $R^{2}(0.9022)$ shows a good fit. The two lines move together.

\section{Conclusions}

The phrase, corporate social responsibility has become very popular in recent years. A lot of definitions are in the literature. There is no generally agreed definition of CSR. According to the literature I think so the corporate social responsibility is a corporation's initiatives to assess and take responsibility for the company's effects on environmental and social wellbeing.

The idea of corporate social responsibility has developed differently around the world because of unique histories, cultures and institutions in the words of Steiner (1971). Based on the literature, I think that the definition of CSR can be classified into two general schools of thought. First group, who claim that the obligation of an organization is to maximize profits by abiding by the corporate rules that prevails, with minimum ethical constraints. Within this group, two further groups can be distinguished. Some writers have taken the view that a corporation should not be concerned with social responsibility. Other people are more cynical in their view of corporate activity. There are, who place greater emphasis on the organization's obligations towards the society. From the perspective of the second main group, I presented the development of CSR's definition in chronological order.

The newest and the most modern wave of interest in corporate social responsibility have been marked by some new development. The dispute is now more about how to make substantial commitments rather than whether to make them at all. There has been an increasing interest in the topic in Europe initiatives on corporate social responsibility (Hinson, 2015). 
The main results of content analysis are as follows:

1. The frequency of appearance of corporate social responsibility (or CSR) was 556,220 in on-line databases. The phrase was mostly in journals and in articles.

2. The frequency of appearance of corporate social responsibility shows an exponential increasing trend in databases. The corporate social responsibility is occurring in more and more scientific research and publications.

3. The first appearance of the investigated phrase in databases was in 1792 in all sciences.

4. The first appearance of the investigated phrase in databases was in 1886 in selected (economic and business) sciences.

I think the results of the study are relevant because:

1. The study collects the most important on-line scientific databases.

2. The study summarizes the most important information about these databases.

3. The study presents the possibility of searching in on-line scientific databases.

4. The study helps people to navigate in the literature of CSR.

\section{Acknowledgements and Research Funding}

The study was funded by the National Research, Development and Innovation Office from the NKFI Fund (K 120044).

\section{References}

1. Balabanis, G., Phillips, H. C., \& Lyall, J. (1998). Corporate social responsibility and economic performance in the top British companies: are they linked? European Business Review, 98(1), 25-44. doi: 10.1108/09555349810195529.

2. Barnard, C. (1938). The Functions of the Executive. Harvard University Press.

3. Berelson, B. (1952). Content Analysis. Free Press, New York.

4. Bowen, H. R. (1953). Social responsibilities of the businessman. Harper \& Brothers, New York.

5. Carnegie, A. (1901). The Gospel of Wealth, and Other Timely Essays. Century.

6. Carroll, A. B. (1979). A three-dimensional conceptual model of corporate performance; Academy of Management Review, 4(4), 497-505.

7. Carroll, A. B. (1991). The pyramid of corporate social responsibility: toward the moral management of organizational stakeholders. Business Horizons, 34, 39-48. doi: 10.1016/0007-6813(91)90005-G.

8. Crowther, D., \& Aras, G. (2008). Corporate Social Responsibility. Ventus Publishing ApS.

9. Dahl, R. A. (1972). A prelude to corporate reform. Business \& Society Review, Spring 1972, 17-23.

10.Davis, K. (1973). The Case for and against Business Assumption of Social Responsibilities. Academy of Management Journal, 16, 312-322. doi: 10.2307/255331.

11.Davis, K., \& Blomstrom, R. L. (1975). Business and society: Environment and responsibility. McGrawHill, New York.

12.Drucker, P. (1984). The Temptation to Do Good. William Heinemann Ltd., London.

13.Epstein, J. L. (1987). Toward a theory of family-school connections: Teacher practices and parent involvement. In: Hurrelman K, Kaufmann FX, Sel FL, editors. Social intervention: Potential and constraints. Walter de Gruyer, Berlin, 121-136.

14.Commission of the European Communities (2001). Green Paper - Promoting a European framework for Corporate Social Responsibility. http://europa.eu/rapid/press-release_DOC-01-9_en.pdf. Accessed 10 January 2018.

15.Commission of the European Communities (2002). Corporate Social Responsibility: A business contribution to Sustainable Development. http://trade.ec.europa.eu/doclib/docs/2006/february/tradoc_127374.pdf. Accessed 10 January 2018.

16.Commission of the European Communities (2011). Corporate Social Responsibility: a new definition, a new agenda for action. http://europa.eu/rapid/press-release_MEMO-11-730_en.htm. Accessed 10 January 2018.

17.Forstater, M., MacDonald, J., \& Raynard, P. (2002). Business and poverty: bridging the gap. Prince of Wales International Business Leaders Forum, London.

18.Friedman, M. (1970). The social responsibility of business is to increase its profits, New York Times, 13 September.

19.Google Books Ngram Viewer https://books.google.com/ngrams/info. Accessed 20 February 2018. 
20.Gyuris, F. (2014). Az egyenlőtlen földrajzi fejlődés koncepciója. Földrajzi Közlemények, 138(4), 293-305.

21.Hetherington, J. A. C. (1973). Corporate Social Responsibility Audit: A Management Tool for Survival. The Foundation for Business Responsibilities, London.

22.Hinson, R. E. (2015). Social Responsibility and Ethics. Final UGBS 207. University of Ghana Business School. https://www.slideshare.net/xtaclesklex/final-ugbs-207-52440758. Accessed 10 January 2018.

23.Holme, R., \& Watts, P. (2000). Corporate social responsibility: making good business sense. World Business Council for Sustainable Development. http://wbcsd.org/web/publications/csr2000.pdf. Accessed 15 February 2018.

24.Horrigan, B. (2010). Corporate Social Responsibility in the 21st Century: Debates, Models and Practices Across Government, Law and Business. Edward Elgar Publishing.

25.Levitt, T. (1958). The Dangers of Social Responsibility. Harvard Business Review, 36, 41-50.

26.Maignan, I., \& Ralston, D. A. (2002). Corporate Social Responsibility in Europe and the U.S.: Insights from Businesses' Self-presentations. Journal of International Business Studies, 33(3), 497-514. doi: 10.1057/palgrave.jibs.8491028.

27.Martinuzzi, A., Krumay, B., \& Pisano, U. (2011). Focus CSR: The New Communication of the EU Commission on CSR and National CSR Strategies and Action Plans. ESDN, Quarterly Report December 2011.

28.Militaru, G., \& Ionescu, S. (2006). The competitive advantage of corporate social responsibility. U.P.B. Sci. Bull., Series D, 68(2), 89-103.

29.McGuire, J. (1963). Business and Society. McGraw-Hill, New York.

30.McWilliams, A., \& Siegel, D. (2001). Corporate Social Responsibility: A Theory of the Firm Perspective. The Academy of Management Review, 26(1), 117-127.

31.Steiner, G. (1971). Business and Society. Random House, New York.

32.World Bank (2006). Beyond Corporate Social Responsibility: The Scope for Corporate Investment in Community Driven Development. Washington, DC. https://openknowledge.worldbank.org/handle/10986/8240. Accessed 10 January 2018. 